\title{
Workforce Diversity and Organisational Survival of Private Hospitals in Niigeria
}

\author{
Dr Omoankhanlen Joseph Akhigbe ${ }^{1}$, Ohiria Igho Shedrack ${ }^{2}$ \\ ${ }^{I}$ Senior Lecturer Department of Management Faculty of Management Sciences University of Port Harcourt \\ Rivers State - Nigeria \\ ${ }^{2}$ Department Of Management Faculty Of Management Sciences University Of Port Harcourt \\ Rivers State - Nigeria
}

\begin{abstract}
This study examines workforce diversity and organizational survival hospitals in Port Harcourt, Rivers State Nigeria. The aim of this study is to exploit the relationship between Workforce Diversity and Organizational Survival of Private hospitals in Port Harcourt. The cross-sectional survey of quasi-experimental design was adopted for this study. Spearman's Rank order correlation coefficient was used to analyze the three null hypotheses at $0.05 \%$ level of significance. The study shows that a significant relationship that exist among dimensions and measures of the predictor variables and the criterion variables respectively, It also revealed that organizational structure as a moderating variable had significant effect on the relationships that exist between the predictor and criterion variable. It was recommended that; Private hospitals management should make policies that will ensure the orientation of surface level diversity as it would stimulate adaptability of the employees in changing business environment, Private hospitals management disposition should be on deep level diversity as this will enhance adaptability in the organization, Private hospitals management should adopt a structure that defines how jobs are formally divided, grouped and coordinated, and it must be considered.
\end{abstract}

Keywords; workforce diversity, Organizational Survival, Adaptability, Dynamic Capability, Deep Level Diversity, Organizational Structure

\section{Introduction}

The $21^{\text {st }}$ century organizations are engaging modalities that will ensure that they survive in the macroeconomic environment full of uncertainty. Gross (1968) discovered that the objective of organizational survival buttresses all other goal, paying consideration to this objective contributes to the satisfaction and implementation of other organizational goals. He maintains that the perception of survival is an unwritten law of every organization. And this suggests that every organization must regard survival as an absolute precondition for serving any interest whatsoever. Consequently, any type of organization that is establish, there are chances that employer's or employee's actions, inactions or counteractions could be a threat to its existence and survival. Decision-makers in various organizations, should have a wider perspective of behaviours to get out the best competences that exist among the workforce, employees behaviours are very likely to be demonstrated in various ways such as in corporate benevolence, market portions level and progression rate, which will most probably improve competiveness (McDaniel \&Gitman, 2008). The focus of global competition and present day certainties facing initiatives appearsdifficult for managers. The chances may be for managers to develop policies that will accommodate the conflicting tastes and preferences of their end users. Organizations are into modifications of their workforcedemographic composition due to legislations, labour and market trends (Triandis, Kurowski\&Gelfand, 1993). Furthermore, varying workforce, workplace and work conditions are posing greater challenges for organizations (Spinks \& Moore, 2007; Grantham \& Ware, 2004) opines that, the prevailing forces affecting the environment of work and workforce is demographics. The changing dispersal of workforce diversity in workplaces is an issue that hasdisturbed the behaviour of employees. Scholars are of the view that diversity causes political and interpersonal conflicts in the workplace (William, Parker, \& Turner, 2007; Noon, 2007). According to Carrell's study (as cited in Collins 2015) defines "workforce diversity as the ways that people differ which can affect a task or relationship within an organization such as age, gender, race, education, religion and culture". This makes up the composition of surface level dimension while Deep-level diversity refers to differences among team members' psychological characteristics, including cognitive abilities, knowledge, skills as well as values, attitudes, and non-performance oriented traits (Harrison, Price, Gavin, \& Florey, 2002). Workforce diversity has become very much relevant today in organizations as predicted by Hudson Institute (1987). Hudson Institute concluded from its research that the ways by which organizations manage workforce diversity are still developing. It can be assume that the characteristics of workforce diversity can be observation while others have psychological characteristics that become evident as members of an organization become personally acquainted. It is an apparent proposition that organization with diverse 
workforce function differently from that with a similar workforce (Milliken \& Martins, 1996; Williams \& O’Reilly, 1998; Webber \& Donahue, 2001).

In this study, the physical and psychological difference in the perspectives that make-up a diversified workforce could be joined to enhance the current growth and survival rate of Private hospitals in Port Harcourt, Rivers state. Thus, this study intend to show the relationship between workforce diversity and organizational survival with a view to recommending strategies that will enable Private hospitals operate at optimum level of survival.

\section{Problem Statement}

According to Timothy, Irinoye, Yunusa, Dalhatu, Ahmed and Suberu (2014), succumbed that Private hospitals are in danger and seen described by poor people management strategies, outdated equipment, poor service delivery, lack of drugs and dysfunctional health statistics system, amid others.

\section{Research Gap}

Empirical evidence has shown that Private hospital management has not properly harnessed the diversity of their workforce, which constituent a threat to survival of Private hospitals. It is based on this background that this study tends to breach the gap in literature by systematically examining the relationship between workforce diversity and organizational survival ofPrivate hospitals.

\section{Operational Framework of Workforce Diversity and Organizational Survival}

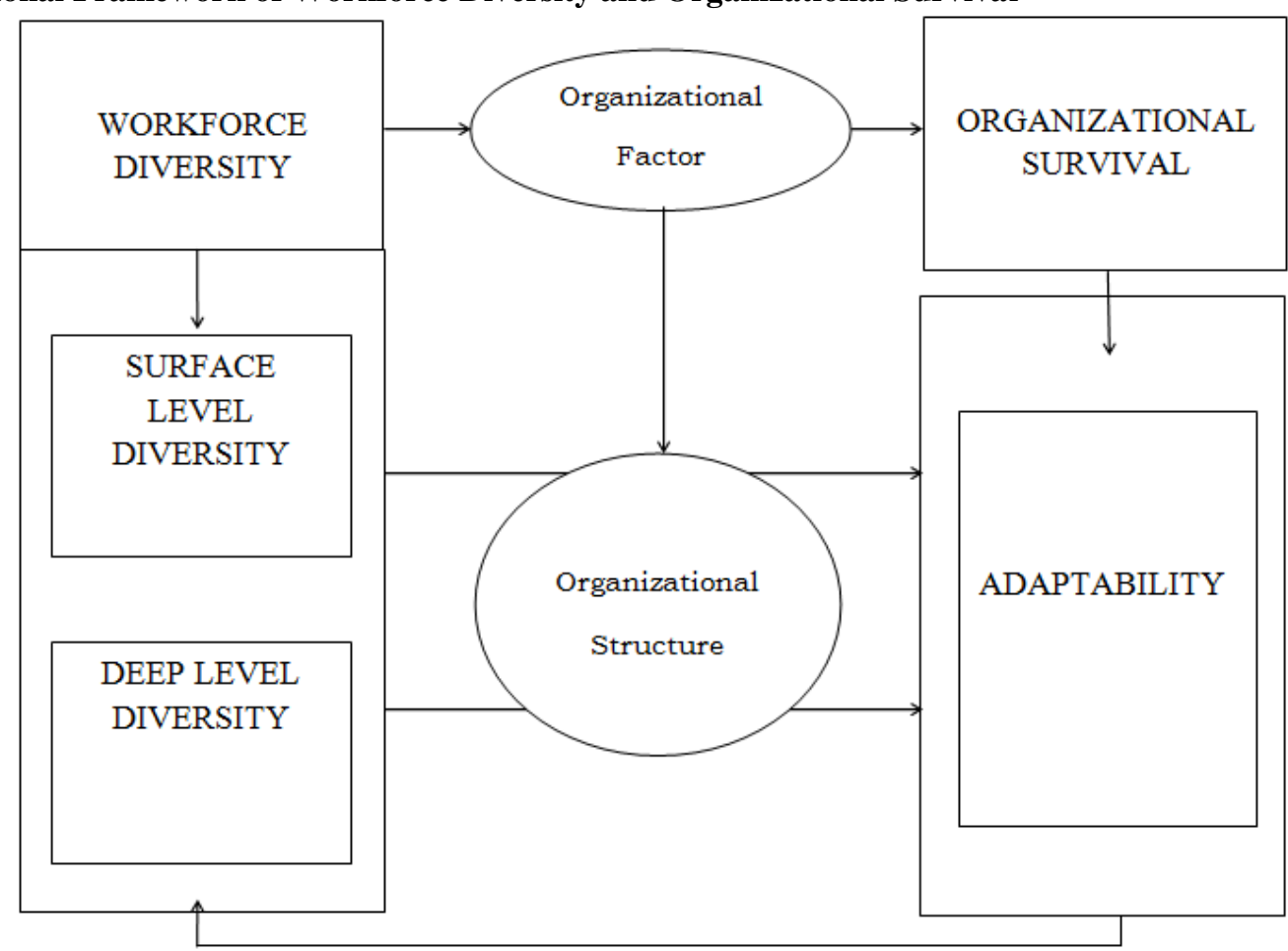

SOURCE: Operationalized by the researcher, 2016.

Tsui\&Gutel, (2000) advocated Surface level\&Deep level diversity.

Zahra,Sapienza, \&Davidsson, (2006) adaptability.

Organizational structure is used as the moderating variable.

\section{Objectives of the study}

The aim of this study is to explore the relationship between Workforce Diversity and Organizational Survival in Private hospitals in Port Harcourt. However, the specific objectives are:

i. To investigate the relationship between Surface level Diversity and Adaptability of Private hospitals in Port Harcourt.

ii. To investigate the relationship between deep level Diversity and Adaptability of Private hospitals in Port Harcourt.

iii. To investigate how organizational Structure moderates the relationship between workforce diversity and Organizational survival in Private hospitals in Port Harcourt. 


\section{Research Hypotheses}

The following null hypotheses were mapped out for the study:

$\mathbf{H}_{\mathbf{0 1}}$. There is no significant relationship between surface level diversity and adaptability of Private hospitals in Port Harcourt.

$\mathbf{H}_{\mathbf{0 2}}$. There is no significant relationship between deep level diversity and adaptability of Private hospitals in Port Harcourt.

$\mathbf{H}_{\mathbf{0 3}}$. Organizational structure does not moderate the relationship between workforce diversity and organizational survival of Private hospitals in Port Harcourt.

\section{Workforce Diversity}

\section{Review of Related Literature}

Conventionally, the word diversity is commonly used to denote demographic arrangement of workforce. Scholars has critically studied diversity exhausting the compositional styleof Surface-level diversity (SLD) which states the extent to which a group is dissimilar on physical features such as age, ethnicity, religion, gender etc. (Tsui\&Gutek, 2000; Fajana, Owoyemi, Elegbede\&Gbajumo-Sheriff, 2011). Furthermore, deep-level diversity (DLD), otherwise understood as dissimilarities as regards to personality, values, and attitudes.(Harrison, Price, Gavin, \& Florey, 2002.Thatcher, Jehn,\&Kanutto, 2003). Employees in organization can solve problems and improve on performance that leads to organizational survival. Diversity concept is now projected to bevital in future for the increasing demographic characteristics of many countries. Organizations should embrace diversity management for them to be totally all-encompassing and have the potential of yielding greater productivity and competitive advantages that will bring about organizational survival. This study examinedworkforce diversity under surface level diversity with its dimensions of gender, ethnicity and religion while deep level diversity with its dimensions of individual perception, values and locus of control.

\section{Surface Level Diversity}

Organization's surface level compositionof the workforce changesdue to labour, market trends, legislation, demographic realities etc. for these changing workforce compositions, managers are facing surface level diversity more frequently in their organizations than they had in time past, (Tsui\&Gutek, 2000). However, three characteristics of surface level diversity were examined. Firstly, gender is among the prominently contemporary discourse and has constituted major challenges to business organizations as more women are gaining opportunity into the workforce now more than ever before. Career progression of women is not as fast as their male counterparts due to career breaks that come about due to family responsibilities. Some organizations provide flexible work programs to help women deal with such challenges (Aosa, 2011). Weiss, Kemmler, Deisenammer, Fleischh, \&Delazer, (2003) were of the opinion that there is no consistent female/male difference in problem solving ability, analytical skill, and motivation, sociability or learning ability. Secondly, ethnicity as a demographic characteristic that is on a personal level, it is usually interchangeable with race. Studies has showed that ethnicity and race are relates to employment outcomes as to hiring decisions, performance evaluations etc. when people understand themselves, it gives more sense of security that will better the business. The Federal character principle that has quota system thatensures different ethnic groups to be represented in any level in the political system and bureaucracy. According to Baridam, (2002) opined that organizations as a political entities is not a recent occurrence and believes that such planning allows individuals with different interests and favorites to come together and engage in exchanges. Thirdly, religion is highly practice by Nigerians over the globe; Nigerians had being practicing traditional religions before the advent of "strange religions". Religion is actually classified among the most visible manifestations of culture, its influence is view in the angles of dressing, ritual, what's forbidden or not, greetings, etc. (Schermerhorn, Hunt \& Osborn, 1995) adds that programs of ethics and moral behavour tend to have manifested from religious beliefs and influence of religion on economic issues can be significant too, for example, the proposal of the Islamic Bank in Nigeria wishes to downplay interests on loans and other financial facilities in line with Islamic doctrines.

\section{Deep Level Diversity}

This is another type of differences that can be observe among workforce in an organization in form of personality, attitudes, life style, beliefs and values (Laio, Chuang \& Joshi, 2008). This deep level diversity differences that are not seen but only perceived rather than objective, may also affect cohesion and other organizational outcomes. According to Riketta (2008) attitudes are said to predict prospect behaviours.Deep level diversity was explored by taking a specific look at individual differences in personality and perception. Firstly, locus of control is an aspect of personality studies. This concept was propounded by Rotter (1954). An individual's Locust of Control refersto the occurrence of event that affects them can be controlled. These beliefs will leads to ways of sharpening attitudes and behaviors that people will adopt. Secondly, perceived equity level is about Equity theory with regards to motivation that describes worker behavior. Adams, (2008) opined that 
equity theory focuseson the employee's perception of work place fairness and equity to ascertain employee satisfaction.Adams (1965) inequity exist where by employee perceives that the ratio of his/her inputs is not commensurate to the ratio ofhis/her output. The equity theory emphasis on how individuals' perceptions of fair treatment in workplace for terms of pay increment annually, how cordial are workers with their supervisors and so on, can positively or negatively influence workers motivation (Ivancevich, Konopaske, \&Matterson, 2005).

\title{
Organizational Survival
}

Organizational survival is the continued existence of organization activities in the occurrence of ups and downsin commerce environs that is categorized with hesitations and unforeseen happenings that intimidate the existence of organizations. These hesitations if not properly coped with; organizations will undergo decrease in market share, profitability, and sales. For organization to strive to survive in a vibrant and competitive business environment, it wholly depends on how effectively the organization learn to adapt in the environment it finds itself and how the organization exercise dynamic capability on its resources efficiently used to the fullest. The endless manifestation of these undesirable trends of the presence of ups and downs in commerce environs can interfere with organization's ability to remain steering its tasks to achieve stakeholders' prospects; a state of affairs that often fallouts in organizations, reputation, customers and goodwill. The significances of poor dealing with these unforeseen happenings will contest the reasons of the organization's very presence and survival, consequently leads to its ultimate folding (Fleming, 2012). According to Gross (1968) organizational survival buttresses all other goal, paying consideration to this objective contributes to the satisfaction and application of other organizational goals.Díez-Martín, Prado-Roman, \&BlancoGonzález (2013) organizational survival rest on the backing that organization obtains from its diverse communities.

\begin{abstract}
Adaptability
Adaptability simply means being flexible when things change, adaptability as used in contemporary generation in management phrase emerges from the field of biology. By means of organizations progressing from side to side of its social economic improvement stage, the significance of long-standing survival and enlargement come to be alive. An adaptable organization is one that is exposed to new philosophies and theories, to functioning individually or as a group. Organizations nowadays by market investigation and environmental X-ray recognize, understand, and transform indications of hesitation in the environs into intimate behavioural modifications that advances their likelihoods ofdevelopment, growthand survival. As opined by Denison (1990) adaptability has three featuresthat influence organization's efficiency. The first among them is the talent to identify and react to external environs. The Second feature is the ability of organization to react to internal customers. While the third feature is ability of organization to reorganize set of behavior and practices that permit the organization to adapt.
\end{abstract}

\section{Moderating role of organizational structure on the relationship between workforce diversity and organizational survivals}

Organizational structure defines how jobs task are formally divided, grouped and coordinated, that is the organogram of organization simply put. Issues concerning work specialization span of control, chain of command, departmentalization, placement and formalization so also centralization/decentralization are issues of discussion under structure (Jacobides, 2007). According to Fontaine (2006) organization structure detect between success and failure for organization also for workforce. Some common types of organizational structure are divisional structure, matrix structure, horizontally linked structure, functional structure and product structure etc. The issue of organization structure may likely include size, jurisdictional clarification, leadership style, member- goal compatibility, level of specialization in the tasks assigned, reward system and degree of interdependence. According to Gennard\& Judge (2005) larger a workforce the greater the outbreak of conflict and that conflict is greatest when group members are relatively younger. Organizational structure organizes human resources for goal directed activities.

\section{Research Design}

III. Methodology

The cross-sectional survey of quasi-experimental design was adopted for this studyPopulation of the Study The population of the study issenior doctors, nurses and consultants at the managerial position of Private hospitals in Port-Harcourt Rivers State, totaling 150 in respect to the information sourced from the department of Service, Ministry of Health Rivers State. Specifically, the study accessible population was ten (10) Private hospitals in Port- Harcourt Rivers State, they were chosen on base on their years of operations (precisely twelve years and above), quality of service delivery etc. by judgmental sampling technique. These ten (10) Private hospitals have senior consultants, Directors, managers, senior medical doctors and nurses. These categories of 
individuals make up the management staff comprising of 73 respondents which are the sample elements of the study. These ten (10) selected private Hospitals as regards to their management staff are shown as follows;

\begin{tabular}{|c|l|c|}
\hline S/N & SELECTED PRIVATE HOSPITALS & $\begin{array}{l}\text { NUMBERS OF } \\
\text { MANAGEMENT STAFF }\end{array}$ \\
\hline 1 & Heritage Medicare Hospital & 7 \\
\hline 2 & Bosom Hospital And Physiotherapy & 6 \\
\hline 3 & Meridian Hospital Limited & 7 \\
\hline 4 & Benod Hospital Ltd & 8 \\
\hline 5 & St Martins Hospital & 8 \\
\hline 6 & Morrison Lawson Memorial Clinic & 7 \\
\hline 7 & Danferd Medical Consultants & 7 \\
\hline 8 & Kendox Medical Services & 8 \\
\hline 9 & Victory Specialist Clinics Limited & 7 \\
\hline 10 & Hopeville Specialist Hospital & $\mathbf{7 3}$ \\
\hline TOTAL & & \multicolumn{2}{|c|}{} \\
\hline
\end{tabular}

Source: Rivers State Ministry of Health, Department of Medical Service 2016.

\section{Sampling Procedure/Sample Size Determination}

Sampling is the process of selecting a representative number from a given population that have common features existing among the elements of the population while sample size is determined when the population elements are too large to be covered. Similarly, since it would be practically tedious for the whole population of private hospitals in Port-Harcourt to be studied, the researcher carefully chose management staff of the ten randomly sampled private hospitals in Port-Harcourt Rivers State, to arrive at 73 respondents which are the sample elements of the study. The researcher chooses the entire sample elements of the study, because the numbers of respondents are not too large and it is within the researcher control, hence there was no need for sample size determination.

Statistical Testing of Hypotheses

\section{Results}

Relationship between Surface Level Diversity (SLD) and Organizational Survival

\begin{tabular}{|lll|r|r|}
\hline & & SLD & \multicolumn{1}{|c|}{ AD } \\
\hline Spearman's rho & SLD & Correlation Coefficient & 1.000 & $.671^{* * *}$ \\
& & Sig. (2-tailed) & .000 \\
& $\mathrm{~N}$ & 70 & 70 \\
\cline { 2 - 5 } & $\mathrm{AD}$ & Correlation Coefficient & $.671^{* * *}$ & 1.000 \\
& Sig. (2-tailed) & .000 &. \\
& $\mathrm{~N}$ & 70 & 70 \\
& & &
\end{tabular}

Source: survey data, 2017

In the assessment of the association between surface level diversity and adaptability, the results indicate significant associations with surface level diversity and adaptability reflecting a rho $=.671$ and a $\mathrm{P}=0.000<$ 0.05 . The results depict a strong, significant and positive correlation between surface level diversity as a dimension of workforce diversity and measure of organizational survival (adaptability).

Relationship between Deep Level Diversity (DLD) and Organizational Survival

\begin{tabular}{|lll|r|r|}
\hline & & DLD & \multicolumn{1}{|c|}{ AD } \\
\hline Spearman's rho & DLD & Correlation Coefficient & 1.000 & $.534^{* * *}$ \\
& & Sig. (2-tailed) &. & .000 \\
& $\mathrm{~N}$ & 70 & 70 \\
\cline { 2 - 5 } & $\mathrm{AD}$ & Correlation Coefficient & $.534^{* * *}$ & 1.000 \\
& Sig. (2-tailed) & .000 &. \\
& $\mathrm{~N}$ & 70 & 70 \\
& & &
\end{tabular}

Source: Survey data, 2017 
In the assessment of the association between deep level diversity and adaptability reveals significant associations with deep level diversity and adaptability (AD) reflecting a rho $=.534$ and a $\mathrm{P}=0.000<0.05$. The results depict highly significant correlations between the variables (deep level diversity and organizational survival).

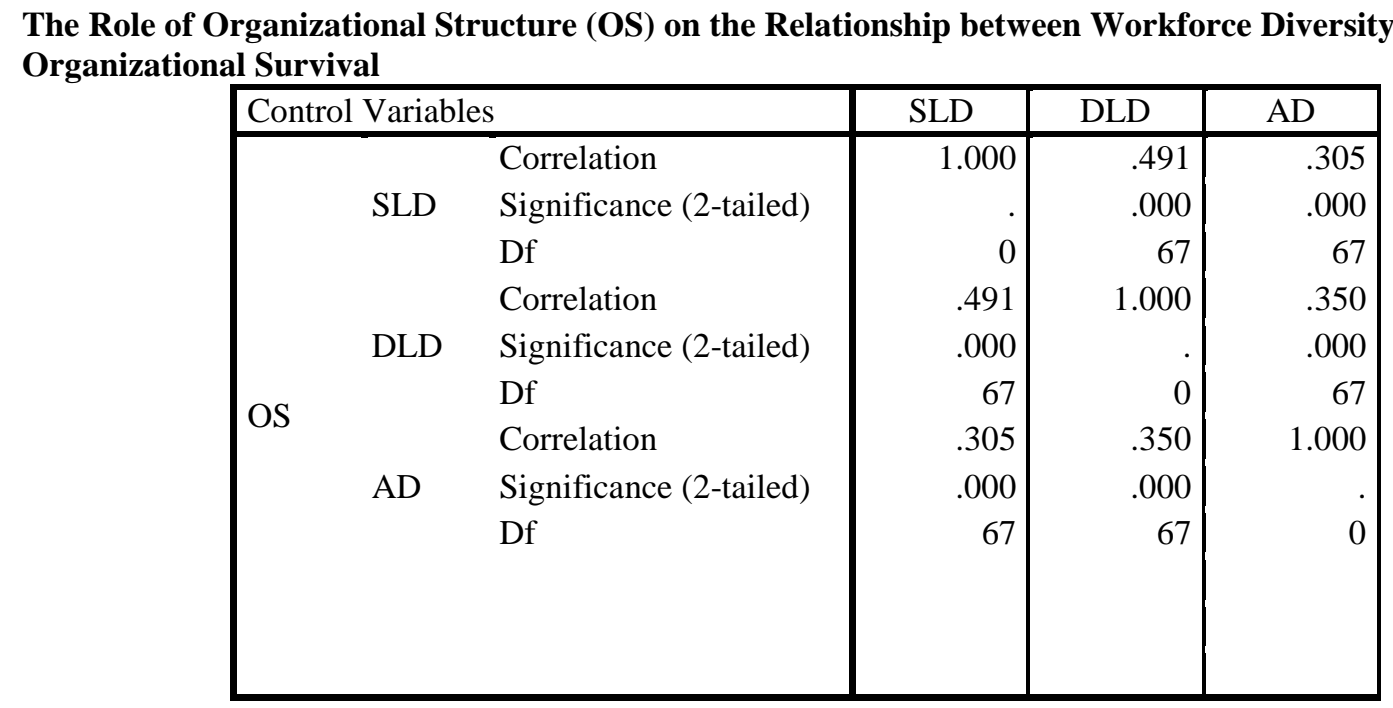

Source: Survey data, 2017

Note: SLD means Surface Level Diversity

DLD means Deep Level Diversity.

OS means Organizational structure

AD means adaptability.

The analysis reveals that organizational structure significantly moderates the relationship between workforce diversity and organizational survival. This is depicted above with the control for organizational structure, revealing a significant level of moderation and effect on the association between dimensions of workforce diversity and measure of organizational survival.

\section{Discussion of Findings}

The results of the analysis reveal that both dimensions of workforce diversity (surface and deep level diversity) are significantly associated with the measures of organizational survival (adaptability and dynamic capability)

i. From hypothesis one, it shows an indicationthat surface level and deep level assorted qualities in associations can be viewed as invaluable and basic to securing authoritative survival. This finding supports with the declaration of Tsui and Gutek, (2000); Fajana et al., (2011), Thatcher et al., (2003), they emphasis that a well comprehension of the idea would enable workers in associations to take care of issues and enhance execution that will prompt authoritative survival.

ii. From hypothesis two,the study reveals that variable such as surface level diversity further facilitate outcomes which invariably translate into organizational survival within the workplace. In such manner, prove from the past investigation of Weiss, Kemmler, Deisenammer, Fleischh, \&Delazer, (2003), were of the conclusion that no reliable female or male contrast in critical thinking capacity, expository aptitude, and inspiration, friendliness or learning capacity. It is additionally watched that no critical distinction in occupation efficiency among men and ladies (Black \&Holden, 1998). The representative's supposition encompassing injustice makes workers to coordinate their occupation endeavors to yields with those of others and respond to the remover of any disparity (Adams, 1965; Nwachukwu, 2007).In a situation where employees notice that remuneration being paid is commensurate to his/her effort contributed to job, it gives the employee motivation to work.

The results for the multivariate analysis reveal that organizational structure as a moderating variable manifested through practices and artifacts reflecting rules and regulations, policies, level of participation, mission, vision clarity and belief systems is a substantial moderator of the relationship among workforce diversity and organizational survival

iii. From hypothesis three structure can be assumed to offer the necessary atmosphere and framework within which activities geared towards surface level, deep level diversity and adaptability are effectively transferred or conveyed to the interested or target members, thereby facilitating the attainment of workers contentment, trust and retention. Organization structure is necessary for both establishment and its workforce, it could detect between success and failure for both the organization and workforce (Fontaine, 
2006). Morgeson, De Rue \&Karam, (2009) set that subject to the kind of authority, correspondence and collaboration, methodology and standards that debilitate or reinforce the outcomes of differing qualities that may come about, for example a powerful initiative style will upgrade conditions that are great for high performing people and groups, including checking bunch shortcomings, making medicinal move to alter shortcomings, and making road of a strong setting

\section{Recommendations}

From the findings of the study, it is therefore recommended that:

i. Private hospitals management should make policies that will ensure the orientation of surface level diversity as it would stimulate adaptability of the employees in changing business environment.

ii. Private hospitals management disposition should be on deep level diversity as this will enhance adaptability in the organization.

iii. Private hospitals management should adopt a structure that defines how jobs are formally divided, grouped and coordinated. Issues like departmentalization, placement and formalization as well as centralization/decentralization must be considered as regards the workforce diversity of hospital management.

\section{Conclusion}

Conclusively, it can be identified that despite the positive association of private hospitals workforce diversity strength, a lot still needs to be done in areas of survival as the firms studied were discovered not to have adequate survival plan as regards dissimilarity in the workplace. Taken together, results of this study will foster a greater understanding of how these organizations could emphasize dissimilarityin the workplace and become totally all-encompassing because diversity has the potential of yielding greater productivity and competitive advantage that will bring about organizational survival. Further, not only will these findings add substantially to several bodies of research, it will inform scholars and practitioners in matters related to numerous human resource functions. Finally, the findings will inspire additional investigations dedicated to exploring co-worker characteristics (including humour) and their complex relationships with characteristics and outcomes of employees.

\section{References}

[1]. Adams, J. S. (1965). Inequality in social exchange.Advances in Experimental Social Psychology,62, 335-343.

[2]. Aosa, E. (2011). Strategic management within Kenya firms.DBA Africa Management Review, (2012). 8(1), 1-21.

[3]. Baridam, D.M (2002).Management and Organisation Theory, $3{ }^{\text {rd }}$ Ed.Sherbrooke Associates.Port Harcourt

[4]. Black, M.M. \& Holden, E. W. (1998)The impact of gender on productivity and satisfaction among medical school psychologist. Journal of clinical Psychology in Medical Settings, March, 117-131.

[5]. Cohen, kim (1999), Commentary on the organisational sciences special issue on complexity, Organization science 10(may-June), 373-376

[6]. Denison, D. R. (1990).Corporate culture and organizational effectiveness.New York: John Wiley \& Sons

[7]. Díez-Martín, F.; Prado-Roman, C.; Blanco-González, A. (2013). Beyond legitimacy: Legitimacy types and organizational success. Management Decision, 51(10), 1954-1969. Retrieved from ABI/INFORM Complete database

[8]. Fajana,S., Owoyemi,O., Elegbede T. \&Gbajumo-Sheriff,M, (2011).Human resource management practice in Nigeria.Journal of Management and Strategy. 2, 57-62.

[9]. Fleming, R. S. (2012). Ensuring organizational resilience in times of crisis.Journal of Global Business Issues, 6 (1), $31-34$. Retrieved from ABI/INFORM Complete database

[10]. Fontaine. C. W. (2006). How organisational structure impacts organisations. First Annual Conference on Organisational Effectiveness.Chicago.

[11]. Gennard, J. \& Judge, G. (2005).Employee Relations. $4^{\text {th. }}$ Ed, London; Chartered Institute of Personnel and development.

[12]. Granthan, C. \& Ware, J. (2004).Demographics and the changing nature of work.Corporate Real Estate Leader, May. 24-26.

[13]. Gross, B. (1968).Organisations and their managing. New York. The free Press, 454.

[14]. Harrison, D. A., Price, K. H.; Gavin, J. H.; \& Florey, A. (2002). Time, teams, and task performance: Changing effects of surfaceand deep- level diversity on group functioning.Academy of management Journal, 45(5), 1029-1045.

[15]. Hudson Institute (1987). American conservative non-profit think tank. Washington, D.C.

[16]. Ivancevich, J. M, Konopaske, R. \&Matterson, M. T, (2005).Organisational behavior and management, $7^{\text {th }}$ ed. New york: McGrawHill/Irwin

[17]. Jacobides, M.G. (2007). The inherent limits of organizational structure and unfulfilled role of hierarchy: Lessons from a near-war organization science.18(3), 455-477.

[18]. Laio, H. Chuang, A. \& Joshi, A. (2008). Perceived deep-level dissimilarity: personality antecedents and impact on job attitudes, helping work withdrawal and turnover:Organisationalbehaviour and human decision processes. 106, 106-124.

[19]. McDaniel,C. \&Gitman, L, J. (2008). The future of business. $6^{\text {th }}$ ed, ohio: Thomson South-Western.

[20]. Milliken, F. J, \& Martins, L. L. (1996).Searching for common threads: Understanding the multiple effects of diversity in organisational groups.Academy of Management Review, 21(2), 402-433.

[21]. Morgeson, F.P., De Rue, D.S. \&Karam, E.P, (2009). Leadership in teams: A functional approach to understanding leadership structure and processes.Journal of Management,XX( X), 1-39.

[22]. Noon, M., (2007).The fatal flaws of diversity and the business case for ethnic minorities.Work Employment and Society, 21(4), 773-784. 
[23]. Nwachukwu, C.C. (2007). Management theory and practice, Onitsha; Africana First Publishers Limited.

[24]. Riketta, M. (2008).The casual relation between job attitude and performance: A meta-analysis of panel studies.Journal of Applied Psychology, 93 (2), 472-481.

[25]. Rotter, J. B. (1954). Social Learning and Clinical Psychology.Prentice-Hall.

[26]. Schermerhorn JR, Hunt JG and Osborn RN (1995) Conflict and Negotiation. In: Schermerhorn JR, Hunt JG, and Osborn RN (eds) Organisational Behavior. New York: John Wiley \& Sons

[27]. Spinks, N \& Moore, C. (2007).The changing workforce, workplace and nature of work: Implications for health human resource management" Nursing Leadership, 20(3), 26-41.

[28]. Thatcher,S.M.,Jehn,K.A.\&Kanutto,E.(2003). Cracks in diversity research: Effects of diversity faultlines on conflict and performance, group decision and negotiation, 12 217-241

[29]. Timothy, G., Irinoye, O., Yunusa, U., Dalhatu, A., Ahmed, S. and Suberu, A. (2014). Balancing Demand, Quality and Efficiency in Nigerian Healthcare Delivery System, European Journal of Business and Management, 6 (23),

[30]. Triandis, H. C., Kurowski, L.L., \&Gelfand, M.J. (1993).Workplace diversity ln M. D. Dunnette and L. M. Hough (Eds), Handbook of industrial and organizational Psychology, 4, 769-827. Palo Alto: Consulting Psychologist Press.

[31]. Tsui, A.S, \&Gutek, B.A. (2000).Demographic Differences in Organisation.New York, Lexington Books.

[32]. Webber, S. \& Donahue, L. (2001).Impact of highly and less job-related diversity on work group cohension and performance: a meta-analysis.Journal of Management. 27(2), 141-162

[33]. Weiss, E.M, Kemmler, G., Deisenammer, E.A, Fleischh, W.W, \&Delazer, M, (2003).Sex Differnces in Cognitive Functions.Personality and individual Differences, September, 853-875

[34]. William, M. H; Parker, K. S; \& Turner.N. (2007).Perceived dissimilarity and perspective taking within work teams. Group and Organisation Management, 32(5), 569-597.

[35]. Williams, K., \&O’Relly, C. (1998). Demography and diversity in organizations: A review of 40 years of research.In B. M, Staw\& R. Sulton (Eds), Research in organizational Behavior. 21, 77-140. Greenwich, CT: JAI Press.

[36]. Zahra, S.A, Sapienza, H. \&Davidsson, P. (2006). Entrepreneurship and Dynamic Capabilities: A Review, Model and Research Agenda. Journal of Management studies, 43 (4), 915-955

Dr Omoankhanlen Joseph Akhigbe. "Workforce Diversity and Organisational Survival of Private Hospitals in Niigeria." IOSR Journal of Business and Management (IOSR-JBM) 19.7 (2017): 34-41. 